Risk governance in an age of wicked problems: Lessons from the European approach to indirect land-use change

J Palmer

Department of Geography, University of Cambridge, UK

Address: Downing College

Regent Street

Cambridge

CB2 1DQ

Email: $\quad$ irp54@cam.ac.uk 


\section{Risk governance in an age of wicked problems: Lessons from the European approach to indirect land-use change}

This paper assesses the recent European governance of risks associated with indirect land-use change (ILUC) arising from biofuel production. Deploying the theoretical concepts of "wicked problems" (Rittel and Webber, 1973), "incertitudes" (Stirling, 2003) and "co-production" (Jasanoff, 2004), it argues that Europe's existing risk governance apparatus has systematically failed to acknowledge the inherent difficulties of both identifying and interpreting knowledge pertaining to this issue, thereby sanctioning a risk management strategy that is both cognitively and democratically illegitimate. In short, existing modes of risk governance have assumed that the questions "what makes ILUC problematic?" and "how problematic is ILUC?" are both resolvable through objective, scientific risk assessments, when in fact they are not. This paper's first contribution is to outline the precise characteristics of ILUC that serve to render it a wicked problem, focusing in particular on the epistemological hurdles facing those who seek to answer the two key questions outlined above. Its second contribution is then to assess the appropriateness of those science-policy relationships which have thus far been cultivated in Europe as part of attempts to deal with this issue.

Specifically here, the reification of "ILUC factors" as the dominant metric of ILUC risk assessment is argued to have comprised a classic instance of "co-production" (Jasanoff, 2004), leading to the systematic "closing down" (Stirling, 2008) of broader political debates around the issue. The paper concludes by contending that Europe's risk governance apparatus will have to strive to be more inclusive, transparent, adaptable and reflexive in the future, particularly given the increasing prominence today of such multi-dimensional "wicked" problems, both in the environmental sphere and beyond.

Keywords: biofuels, indirect land-use change (ILUC), wicked problems, incertitudes, co-production

\section{Introduction}

For at least four decades, scholars of policymaking in contemporary modern democracies have been virtually unanimous in contending that it is the intrinsic complexity and uncertainty of society's most troubling problems which renders them so tenacious. Whilst the terminology used by academics to discuss these issues is diverse ${ }^{1}$ - Rittel and Webber (1973) talk of 'wicked problems', Schön and Rein (1994) of 'intractable policy controversies', and Weinberg (1972) of 'trans-scientific questions' - the fundamental insights being conveyed are remarkably similar. Firstly, when confronting wicked problems, scientific data and evidence, colloquially referred to outside the scientific community as "the facts", do not

\footnotetext{
${ }^{1}$ For the sake of consistency, the term "wicked problem" will be adhered to throughout this paper when referring to such complex and uncertain issues.
} 
identify themselves. Controversy surrounding such problems can often stem, therefore, from disagreements over the types of knowledge and evidence that should count as scientific, or even as relevant, in the first place. Secondly, and perhaps more importantly, even where "the facts" pertaining to a particular wicked problem are settled, those facts cannot speak for themselves in the policy process. Thus, attempts to resolve such problems typically owe their protracted nature not just to the difficulties bound up in determining what "the facts" of a given matter are, but also to the 'remarkably difficult and controversial task' (Ney, 2009: 28) of establishing what those facts ultimately mean for policy ${ }^{2}$. In short, wherever risk regulators confront wicked problems, identifying and interpreting knowledge and evidence both become highly problematic tasks.

But what precisely is it that makes some problems so complex and uncertain? Perhaps more importantly, what are the implications of wicked problems for the precise ways in which legitimate and effective risk governance is to be achieved in modern democratic states? Is it any longer sufficient to rely upon seemingly objective, technocratic risk assessment as the harbinger of "truth speaking to power" in the regulation of contemporary risks? This paper seeks to address these questions through an in-depth assessment of the recent European governance of one particularly complex and multi-dimensional problem at the nexus of several policy agendas - that of indirect land-use change (ILUC) arising from biofuel production.

Biofuels ${ }^{3}$ can be defined succinctly as 'renewable fuels derived from biological feedstocks' (Koh and Ghazoul, 2008: 2451). Typically they are seen as carbon neutral, since

\footnotetext{
${ }^{2}$ Simple shortages of "facts" can therefore never fully explain the persistence of a truly wicked problem. Indeed, some have argued that society probably possesses too much knowledge, or 'an excess of objectivity' (Sarewitz, 2000), about particularly complex problems like climate change (Hulme, 2009; Ney, 2009).

${ }^{3}$ Whilst biofuels have both stationary and mobile applications, and may theoretically take solid, liquid or gaseous form, this paper deploys the term to refer exclusively to liquid, hydrocarbon-based biofuels whose primary purpose is to directly replace some portion of the petrol and diesel consumed by the vast majority of Europe's road transport vehicles.
} 
upon combustion they theoretically release into the atmosphere only that carbon which was sequestered during their growth as plants. Their political appeal is multi-faceted; modern internal combustion engines can run almost entirely unhindered upon a blend of fossil and non-fossil hydrocarbons (i.e. petrol with bioethanol or diesel with biodiesel), such that biofuels may begin immediately to reduce the carbon footprint of the road transport sector, whilst simultaneously quelling motorists' dependence upon oil that is predominantly sourced, usually expensively, from some of the world's most politically volatile regions. Furthermore, with recent rises in global biofuel demand having effectively created an entirely new market for the agricultural produce of both developed and developing economies ${ }^{4}$, many have argued that biofuels will also serve to indirectly boost rural incomes and employment. In anticipation of all of these alleged benefits, European policymakers proposed a Biofuels Directive in 2003, instituting a series of relatively modest, non-binding targets for biofuel consumption across the Union's road network (EC, 2003). With the passing of the more recent Renewable Energy Directive (RED) in 2009 (EC, 2009a), these targets became mandatory, and were also increased to stipulate that $10 \%$ of fuel by energy content should be derived from renewable sources, including but not limited to biofuels ${ }^{5}$, by the year 2020 .

Biofuels are not without their problems, however. Various doubts surrounding the authenticity of their environmental and socio-economic credentials (Bailey, 2008; FOE, 2007; Kutas et al., 2007; Royal Society, 2008; RSPB, 2008), as well as concerns about their potential impact upon global food and feed prices (Mitchell, 2008; The Times, 2008), have run high for a number of years (for contrasting analyses of recent political debates

\footnotetext{
${ }^{4}$ The majority of biofuels consumed by motorists in the European Union today are derived from staple food crops such as wheat, oilseed rape, sugar cane, soy and oil palm. It is therefore reasonably simple for producers of such crops to begin supplying their produce to the biofuels sector, since little or no change in farming practices is required to do so.

${ }^{5}$ Despite increasingly rapid developments in alternative fields, and particularly in the electric vehicle industry, it is widely expected that the majority of this $10 \%$ target (i.e. between approximately $6 \%$ and 9.2\%) will be met in 2020 through biofuel blending (Bowyer, 2010; Al-Riffai et al., 2010).
} 
surrounding these issues at the UK level, see Dunlop, 2010; Palmer, 2010). Couched within this broad set of tensions, the specific issue of ILUC, whereby biofuel production displaces existing agricultural activity into new territory (figure 1), has proven particularly controversial, not just because it engages actors with diverse interests from agricultural, development, energy, environmental and trade policy fields, but also because it is a process that cannot be directly observed or measured. As such, all attempts to reach a political consensus on the issue - underpinned primarily by the commissioning of four in-depth scientific reports, as well as the holding of two public consultations and one expert workshop - have to date proved unsuccessful ${ }^{6}$. Characterised as it therefore is by 'uncertainty over consequences, diverse and multiple engaged interests, conflicting knowledge claims, and high stakes' (Lorenzoni et al., 2007: 65), the political debate over ILUC in Europe today arguably constitutes an archetypal wicked problem, leading to what Schön and Rein (1994) would term "intractable policy controversy".

Of course, that politics takes on an argumentative dimension (Fischer and Forester, 1993) when faced with wicked problems has become something of a truism in modern political science ${ }^{7}$, underpinning the emergence of an entire field of research labelling itself interpretive policy analysis (Yanow, 1996) ${ }^{8}$. Yet, whilst scholars in this field have enquired in great detail into the implications that such problems may have for the ways in which political agendas are set, issues defined, alternatives weighed up, and policy choices ultimately made in advanced modern democracies (see for instance Hajer, 1995; Kingdon,

\footnotetext{
${ }^{6}$ Indeed, on December 22 2010, in a de facto admission of political dissensus on the issue of ILUC, the European Commission adopted a report which announced little more than that it would not be able to present a full impact assessment on the issue until at least July 2011 (EC, 2010a). As of October 2011, the promised impact assessment has still not been published.

${ }^{7}$ Of course, policy scientists still disagree about the actual extent, and indeed significance, of this argumentative activity, but today there remain very few scholars who would deny its existence altogether.

${ }^{8}$ In short, this field 'seeks to identify both the specific meanings, intended and made, of specific policies and how those meanings are communicated and variously interpreted' (Yanow, 1996: 222).
} 
2003; Stone, 1988), they have reflected remarkably infrequently upon the nature of the very complexities and uncertainties that imbue those same problems with such characteristic tenacity in the first place. The first aim of this paper is therefore to document the various dimensions of this complexity and uncertainty as it plays out in the case of ILUC, drawing in particular upon the concept of "incertitude", as deployed most notably by Stirling (2003).

Subsequently, the paper will then move on to assess the corresponding appropriateness of those science-policy relationships that have thus far been cultivated by participants seeking to address ILUC in the European risk governance community. Specifically, this will involve scrutinising (1) the processes through which certain types of knowledge and evidence have gained legitimacy and credibility in policy debates about this problem, and (2) the politics of the Union's relevant policymaking processes themselves both formal and informal. Of particular use throughout the analysis will be the theoretical concepts of "co-production" - an idiom connoting that "the ways in which we know and represent the world are inseparable from the ways we choose to live in it' (Jasanoff, 2004: 2) - and "closing down", whereby 'unitary and prescriptive policy advice' emerging from the risk governance process is argued to 'seriously downplay the scope for legitimately divergent interpretation' of a given problem (Stirling, 2008: 279).

\section{The dilemmas of identifying and interpreting knowledge about ILUC}

\section{Heterogeneous Risks}

Indirect land-use change (ILUC) occurs when biofuel production displaces pre-existing agricultural activity - usually the cultivation of crops or the grazing of livestock - into new geographical territory. In simple terms it therefore comprises the indirectly stimulated conversion of a non-agricultural landscape into an agricultural one. Thus, ILUC can legitimately be associated with a diverse range of risks; both environmental and socio- 
economic in nature (see Table 1). In environmental terms, for instance, the clearing of certain non-agricultural landscapes through ILUC could lead to an irreversible 'pulse release of greenhouse gases' (Clift and Mulugetta, 2007: 25) that would take decades or even centuries to recoup ${ }^{9}$, and might also risk foregoing carbon sequestration that would have occurred if that landscape had been left undisturbed (Searchinger, 2010). In this sense ILUC potentially poses a risk to everyone on the planet, since it could exacerbate global climate change by placing more greenhouse gases (GHGs) into the atmosphere than it is possible to mitigate through the use of biofuels as a renewable alternative to fossil fuels in the road transport sector. In other quarters, concerns have been raised over the impact that ILUC might have upon biodiversity (e.g. Danielsen et al., 2009), with one study arguing that 'it would take several hundreds of years to compensate' for any short term direct biodiversity loss initiated by biofuel production through the positive longer term effects of GHG emissions reductions (Ros et al., 2010: 9). Here ILUC potentially poses a risk to both non-human and human populations, firstly by threatening to remove habitat critical to the survival of vulnerable plant and animal species, and secondly by threatening to reduce the quality and quantity of various “ecosystem services" upon which present human lifestyles often critically depend.

In the socio-economic realm, by contrast, concerns have been raised over the potential impact that ILUC might have upon the land rights and livelihoods of indigenous populations in parts of the Global South, particularly where so-called "land-grabbing" is documented to have taken place (see for instance Carmody, 2011; Matondi et al., 2011). Of course, ILUC resulting from biofuel production forms only one part of a much wider equation in this respect, and yet it is also true that fulfilment of biofuels mandates in the Global North will

\footnotetext{
${ }^{9}$ It has been estimated for instance that the conversion of rainforests, peatlands, savannahs or grasslands to agricultural landscapes could result in GHG emissions of between 17 and 420 times the magnitude that any subsequently produced biofuels would be able to mitigate on an annual basis (Fargione et al., 2008).
} 
inevitably require the cultivation of vast amounts of arable land. Indeed, a comprehensive study sponsored by the International Council for Science estimated in 2009 that to meet $10 \%$ of global transport fuel needs by 2030 through biofuels would require the cultivation of between $118 \mathrm{~m}$ and 508m ha of such land (Ravindranath et al., 2009), a figure which compares to a present global total area of arable land today of around 1,400-1,500m ha. In a context of a rising global population (as well as increasingly land-intensive diets in many parts of the world), the contribution of biofuels to overall increases in demand for agricultural land at a global level can be legitimately called into question. As such, ILUC potentially poses highly significant risks (i.e. loss of land that provides a critical means of subsistence and/or serves as a major source of income; declines in local food supply leading to greater susceptibility to food price increases) to indigenous communities, especially where existing land rights are not formally articulated or recognised, or where the resources and capital required to access key legal institutions (through which those rights could be defended) are not present (Ariza-Montobbio et al., 2010; Vermeulen and Cotula, 2010).

Finally, at the boundary between socio-economic and environmental risks, ILUC can also be identified as a potential driver of water and soil resource degradation and depletion (e.g. Weis, 2010). Amongst other things here, a sudden and potentially large demand for irrigation, as well as the likely intensive application of chemical pesticides and fertilisers, could pose threats to both the natural environment (for instance through eutrophication driven by enhanced nitrogen runoff to rivers and other water courses) and human populations (either through the contamination of groundwater resources or more simply by compromising local water security).

In short then, ILUC is clearly a multi-dimensional policy problem; in various quarters and by various groups, it has been identified as at least a partial driver of a wide range of social, economic and environmental risks. As a consequence, providing an answer to the 
question "what makes ILUC problematic?" is far from a simple task. Indeed, defining the very nature of the problem to which risk regulators must ultimately respond when addressing ILUC is a highly politicised process subject to quite profound ambiguities, where 'a variety of divergent - but equally reasonable - framing assumptions' (Stirling, 2003: 45) co-exist, and cannot be adjudicated between on purely objective terms.

\section{Innumerable Incertitudes}

It is not just at the point of defining the very problem posed by ILUC that such difficulties exist, however. Indeed, even if a particular framing of the issue at hand could be universally agreed upon (i.e. if relevant bodies of knowledge and evidence could be unproblematically identified), a series of further epistemological hurdles remain in the characterisation and measurement of the risks that are concomitantly recognised (i.e. conflicting interpretations may still be made of any knowledge and evidence pertaining to those risks).

At base level, and no matter what one's overall framing of the problem of ILUC, any attempt to formulate knowledge and evidence about the risks it poses must successively answer questions about (1) the area of additional arable land required to fulfil forecast future demand for biofuels in the European Union, typically by $2020^{10}$, (2) the geographical locations where this new land will be brought into production, and (3) the direction and magnitude of the various impacts which will ultimately result. Indeed, attempts to answer these three questions ultimately constitute the three main stages of all models presently used to assess risks emanating from ILUC in the European risk governance community (see for instance figure 2, a schematic example of a model designed to calculate the GHG emissions resulting from this process).

\footnotetext{
${ }^{10}$ Importantly here, modellers determine not simply the volume of biofuels that will be consumed in Europe as a result of the Renewable Energy Directive, but rather the difference between this quantity, and that which would be consumed under a hypothetical "baseline" scenario where the policy did not exist (DG Energy, 2010).
} 
To answer the first of these three critical questions, one must first establish the likely impact that will be exerted by the targets contained in the Renewable Energy Directive upon agricultural commodity prices, and thus upon agricultural yields ${ }^{11}$. Unfortunately, the range of variables that can already be identified as partial determinants of global agricultural commodity prices is vast. Amongst other things, the price of crude oil, demand shifts for food and other agricultural produce, the structure and implementation of a vast array of agricultural subsidy schemes, and of course climatic variations, all play significant roles in determining the direction and magnitude of change in commodity prices globally (see for instance Koh and Ghazoul, 2008: 2455). Of course, many of these variables are themselves largely dictated by social processes (with the exception of changes in climate), and are therefore extremely difficult to model in any positivist sense (see Berkhout et al., 2002: 85). Perhaps more problematically still however, their combined impact upon grain prices is in turn the subject of poorly understood but nonetheless intense economic speculation (being channelled for instance through 'futures markets'), which itself serves to distort those prices' behaviour substantially (Chakrabortty, 2011; RFA, 2008: 61).

Determining the actual impact of the EU's biofuel targets upon agricultural commodity prices is therefore a daunting task. Even if it can be assumed that the full cohort of variables impacting upon these prices is known and well understood, one certainly cannot presume a full understanding of the relationships operating amongst those variables; indeed, such relationships may not be linear or quantifiable as such. At this point therefore, studies of the risks posed by ILUC are forced to confront 'complex interactions and path-dependencies in the co-evolution of social, technological and natural systems' (Wynne et al., 2007: 36), or

\footnotetext{
${ }^{11}$ Interestingly, since yields and commodity prices are both strongly correlated with climatic variations, a positive, causal relationship between the former two variables has never been empirically verified (DG Energy, 2010: 16).
} 
indeterminacies, which mobilise ab initio against the calculation of a definitive area of land that will be required to fulfil demand for biofuels under the EU's existing policy.

Of course, since ILUC cannot be physically observed, the task of determining precisely where any new land will be brought into production as a result of the EU's Renewable Energy Directive (RED), which constitutes the second key question identified above, is plagued by similar sorts of indeterminacy. In seeking to predict the geographical manifestation of ILUC, models typically deploy one of two broad approaches, either extrapolating from a historical land-use change data set that is deemed representative of future trends (but which only applies to a specific time period and region), or devising a set of parameters from scratch, based upon subjective judgements of the factors that are most likely to play a role in mediating this process. In both cases of course, it is inevitable that a priori judgements concerning the nature of the very relationships that are being modelled will play an important role in governing the form taken by the models themselves. Attempts to answer this second question therefore exemplify the so-called "experimenters' regress" identified by Collins and Pinch (1998); in the absence of any firm knowledge about the correct answer to a given question, estimates of that answer can only be judged against assumed theories of what the answer probably is, thereby inviting predilections and biases into the scientific process. Put simply, under conditions of indeterminacy, the relationship between what is already known about a complex process on the one hand, and the commitments and choices of those studying that process on the other, is mutually constitutive (Wynne et al., 2007).

Finally, answering the third key question identified above involves estimating the actual magnitude of the impacts resulting from ILUC instigated by the EU's RED. But over what timescale is it most appropriate to judge these impacts? Typically models elect to assess the impacts of ILUC over a period of twenty or thirty years (though occasionally alternative timeframes are used). Yet, crucially, this decision cannot be taken objectively; instead it is 
reliant upon assumptions regarding the probable length of time for which biofuels will play a significant role as a propulsive technology in Europe's road transport sector. As highlighted by the presence of divergent possible framings of ILUC that could legitimately be adopted by the risk governance process, this simple example clearly demonstrates that the process of assessing ILUC risk cannot be conducted in the absence of subjective judgements on the part of the very practitioners for whom those same assessments are supposed to provide objective knowledge and evidence. Instead, the entire process of formulating such knowledge and evidence is subject to ambiguities, or equally legitimate but nonetheless incompatible framings.

Beyond these problems of indeterminacy and ambiguity, there are also further dimensions to the complexity and uncertainty of ILUC which it is important to document here. The first of these simply takes the form of conventional, or strict, scientific uncertainty, defined by Knight (1921) as 'randomness with unknowable probabilities'. In a hypothetical model whose aim is to quantify the GHG emissions emanating from ILUC for instance, this type of uncertainty exists in scientific knowledge of soil-carbon levels prevailing under different landscapes. Present estimates of the quantity of carbon present in soils under tropical rainforests vary, for instance, by approximately 500\% (DG Energy, 2010: 23). Of course, in contrast to the indeterminacies identified above, this type of uncertainty could theoretically be reduced, or perhaps even eradicated, through further scientific research. However, the likely expense of time, effort and financial resources that would be required to achieve this feat would be vast indeed. As a result, risk assessments are for now obliged to make judgements regarding the relative reliability of divergent estimates of soil carbon levels, thereby being forced once again to confront the type of "experimenter's regress" already outlined above. 
The final dimension of the complexity and uncertainty inherent to ILUC to mention here is that of ignorance. For Spiegelhalter and Riesch (2011), ignorance prevails in situations where 'we don't know what we don't know about the completeness and validity of our knowledge, which by definition escapes recognition.' Examples of areas where ignorance might pervade estimates of the impacts of ILUC are necessarily impossible to conjure, of course. Nonetheless, it is germane here to bear in mind that the impact of ignorance upon the effectiveness of risk governance is likely to be particularly prominent where indeterminate systems such as those highlighted in the preceding paragraphs are being studied, since in these cases even the 'level of uncertainty itself cannot be known for certain' (Pielke, 2007: 66).

In sum, it is clear that there exist various different qualities of complexity and uncertainty inherent to the problem of ILUC, including not just strict scientific uncertainty, but also indeterminacy, ambiguity and ignorance. When present together, these epistemological phenomena might be viewed as the quintessential characteristics of wicked problems, collectively rendering the tasks of identifying and interpreting relevant knowledge and evidence hugely difficult. Indeed, we might argue that the 'uncertainty over consequences, diverse and multiple engaged interests, conflicting knowledge claims, and high stakes' identified by Lorenzoni et al. (2007: 65) as the quintessential symptoms of wicked problems ultimately find their root cause variously in ambiguities, indeterminacies, uncertainties and ignorance. To avoid neologisms, the term incertitude, borrowed from the work of Stirling (2003), is proposed as an overarching collective noun that might usefully be deployed to denote the full suite of these characteristics. Table 2 provides a concise definition of each, along with some illustrative examples from the realm of ILUC. 


\section{Governing the risks arising from ILUC - Internalising incertitudes?}

In light of the complex of incertitudes which collectively serve to render ILUC a wicked problem, the remainder of the paper now seeks to assess the corresponding suitability of those risk governance procedures which have been deployed in Europe to try and manage this issue, beginning from 2008. Drawing upon a combination of documentary evidence and the testimony of various well-placed experts, this section's overarching aim is to assess the science-policy dynamics underpinning the European governance of ILUC risk in the light of a growing body of academic work - emanating from fields as diverse as Science and Technology Studies (STS) and deliberative democratic theory - which has attempted to think through the political implications of a widely perceived qualitative shift in the nature of the most prominent risks facing modern society over the past two decades or so (Giddens, 1990; Beck, 1992). Particular focus here will be placed upon the processes through which a dominant "framing" of ILUC has been reified within the European risk governance community since early 2008 , as well as the means by which certain types of knowledge and evidence pertaining to ILUC have been endowed with influence and legitimacy in subsequent political debates around the issue. Furthermore, the analysis will also address the politics of the EU's policymaking processes themselves - both formal and informal - since these have been the source of much controversy in Europe over the past two years.

\section{Conceptualising and measuring ILUC-The co-production of a policy problem}

At base level, any study of science-policy interactions within the risk regulation community surrounding ILUC must begin by examining the roots of the dominant "framing" of this problem which exists in Brussels. In simple terms, this framing conceives of ILUC as a problem that is primarily composed of unforeseen GHG emissions, such that the vast array of alternative potential social and environmental impacts set out in Table 1 are barely 
acknowledged, and in any case certainly not seen as deserving of political attention. Thus, article 19(6) of the Renewable Energy Directive legally obliges the European Commission to focus in its research into ILUC exclusively upon "reviewing the impact of [ILUC] on greenhouse gas emissions and addressing ways to minimise that impact” (EC, 2009a: L140/40).

In seeking to identify the origins of this framing, it is undoubtedly critical to note that, in the years preceding the identification of ILUC as a potential side-effect of biofuel production, existing assessments of the broader impacts of biofuels had themselves focused predominantly upon lifecycle GHG emissions. Indeed, as one official working in the European Commission explained of pre-existing debates around biofuels:

'Lots of people were saying "well you need to ensure that all the attributes [of biofuels] are good"; we said "well actually the only one you can really calculate - you can really measure - is the GHG impact".' (Interview, 25th June 2010).

As such, this stance effectively led to the assembly of a cognitive framework in the biofuels policy community emphasising GHG emissions as the most important characteristic of biofuel production. When it emerged, the problem of ILUC was therefore automatically interpreted within the terms set out by this framework, and viewed as a GHG emissions issue. Moreover, and possibly as a result of this same dynamic, it is also notable that many of the scientific studies (Danielsen et al., 2009; Fargione et al., 2008; Laurance, 2007; Searchinger et al., 2008, 2009) which originally sought to draw attention to ILUC were successful precisely because they provided an indicative first-order approximation of the impact this process might have on the GHG footprint of biofuels consumed in Western countries.

In short, and in spite of the marked ambiguities surrounding the question of what ultimately renders ILUC problematic for society, social processes rooted in both the scientific and the political realms in Europe interacted from an early stage in the ILUC debate to drive through a dominant framing of this problem which emphasised GHG emissions above all other potential impacts. In Jasanoff's (2004) terms, the very definition of the problem that is 
constituted by ILUC which still dominates in Europe today can therefore be said to have been co-produced, emerging not from any objective characteristic of this process itself, but instead from the mutually reinforcing activities of scientists and political actors seeking to find ways of pinning that process down within pre-existing institutional and cognitive frameworks.

At a more specific level, the mutual interactions of science and politics can also be seen as having contributed significantly to the subsequent emergence of the concept of "ILUC factors" as the dominant metric of risk assessment deemed applicable to this problem. Essentially, this metric seeks to distinguish between the quantities of GHG emissions resulting from ILUC that can be attributed to different types of biofuel, as defined according to the primary feedstock (such as sugar cane, oilseed rape or wheat) from which they are processed and the geographical location in which they are produced. Thus, a typical ILUC model might conclude that bioethanol derived from wheat grown in the UK has a much smaller ILUC GHG footprint, or "ILUC factor", than biodiesel derived from oil palm grown in Malaysia. Indeed, many of the scientific reports addressing ILUC that have been conducted on behalf of the European Commission since 2008 communicate their final estimates of the GHG impacts of this process in a way that corresponds directly to this broad metric, as seen for instance in figure 3 .

Not dissimilarly, in the political sphere, both of the European Commission's official public consultations on the issue of ILUC clearly sought to raise the profile of a policy proposal that would discriminate between different types of biofuel using this type of metric. Thus, in its initial pre-consultation document of 2009 (EC, 2009b), the European Commission explicitly sought to elicit the views of Member States and stakeholders regarding the feasibility of a range of potential policy responses, of which arguably the most sophisticated would have directly relied upon the ability of modellers to accurately and reliably calculate ILUC factors. Similarly, in its full public consultation document of 2010 
(EC, 2010b), whilst the Commission identified four separate "courses of action"12 that could potentially be taken in response to ILUC, only in the case of the third of these options ("take action by discouraging the use of some categories of biofuel") were illustrative "example" policies detailed, with particular emphasis again being placed on those options that would ultimately rely upon the accurate calculation of an ILUC factor.

On the surface at least, seeking to determine the ILUC GHG footprint attributable to different types of biofuels seems entirely reasonable (not to mention politically appealing). Yet, as one policy analyst working for the Dutch environmental assessment agency (PBL) points out, 'an ILUC emissions factor cannot be a characteristic of a biofuel [because it results from] the interaction of that biofuel with the global system' (Interview, $15^{\text {th }}$ June 2010). Expressed differently, this means that the values of particular ILUC factors will inevitably evolve as part of a dynamic, global system of agricultural and energy commodity markets that will themselves shift in response to a range of factors, including overarching economic conditions, climatic fluctuations, and changes in the regulatory environment. Most perversely of all, this means that the true value of any "ILUC factor" will itself evolve in response to any biofuels policy incentive or disincentive that seeks to discriminate on the basis of that factor's estimated magnitude (by virtue of altering the extent to which particular types of biofuels are deemed economically attractive by potential producers). In short, the relationships mediating between policy interventions predicated upon the estimation of ILUC factors, and the true value of those factors themselves, are inherently indeterminate.

In light of this indeterminacy, we may legitimately subscribe to the view of the aforementioned policy analyst in contending that 'there is no ILUC emissions factor for biofuels; scientifically it doesn't exist' (Interview, $15^{\text {th }}$ June 2010). The concept of the ILUC

\footnotetext{
${ }^{12}$ These four alternatives were (1) "take no action for now", (2) "take action by encouraging the use of some categories of biofuel", (3) "take action be discouraging the use of some categories of biofuel" and (4) "take some other form of action".
} 
factor is therefore - like the framing of ILUC from which it derives - far from an objective one; measurements of this supposedly intrinsic characteristic of different biofuels are not simply waiting to be extracted from the real world through rational scientific enquiry. And yet, in spite of this fact, mutual interactions between the political sphere in Europe (where actors have strived hard to obtain robust, quantitative estimates of the GHG impacts of ILUC that are well-suited to existing regulatory tools such as life-cycle assessment), and the scientific sphere at a global level (where actors have arguably sought to gain political attention, and concomitant research funding, by producing models that appear to satisfy these requirements), have successfully managed to establish the concept of the ILUC factor as the dominant metric of risk assessment in this debate. Once again, the manner of this reification can be viewed as a classic example of "co-production", exemplifying the ways in which 'knowledge and its material embodiments are at once products of social work and constitutive of forms of social life' (Jasanoff, 2004: 2).

\section{The politics of risk regulation: “Closing down" through co-production?}

In spite of the sheer variety of potential risks that could potentially arise from ILUC, the specific interactions of scientific and policy communities thus far outlined have without doubt operated to tightly restrict political debate surrounding this problem in Europe to date. As a senior European Commission official remarked in mid-2010:

'The debate has reached a point where your contribution only has any credibility if you've engaged with the science. And that sets a very high bar to entry [whereby] only the people who are prepared to take the time to read these...reports can [participate].' (Interview, 8th July 2010).

This official's reference to "the science" can legitimately be read here as a shorthand term evoking the full suite of modelling exercises conducted on the European Commission's behalf by various bodies, all of which were exclusively oriented towards facilitating an assessment of the GHG impacts of ILUC. As one biofuels campaigner working in Brussels 
for a non-governmental organisation with strong interests in environmental protection therefore explained:

'We are reduced to discussing ILUC modelling and the assumptions here and the assumptions there, which honestly I find quite depressing.' (Interview, 29th July 2010).

It short, it is therefore clear that a highly technical, model-based discourse (Hajer, 1995) emphasising only the GHG impacts of ILUC has emerged to dominate wider discussions of this problem in Brussels. In this setting, only those actors whose arguments conform to this technical discourse, and who deploy the full 'ensemble of ideas, concepts and categorisations' (Hajer, 1995: 44) (including of course the central concept of the ILUC factor) to which it subscribes, can be assured that their views and ideas will be taken seriously by political decision-makers. Crucially, whilst this discourse has provided the European ILUC debate with a clear focus, it has also automatically discredited arguments underpinned by alternative perspectives on the issue, as evidenced by a further quote from the aforementioned biofuels campaigner:

'There is a quite terrifying moral aspect to [ILUC] which is not present in the debate, and to be honest, that level of argument, you are not able even to make in Brussels, because otherwise you are seen as a sort of "green loony".' (Interview, 29th July 2010).

The reification of ILUC modelling, as well as the concomitant co-production of ILUC factors, can therefore be said to have facilitated what Stirling (2008) calls the "closing down" of the ILUC debate itself, running directly against the grain of broader calls in academic circles for greater inclusivity in the governance of what are widely perceived to be increasingly complex and uncertain risks (Funtowicz and Ravetz, 1993; De Marchi and Ravetz, 1999).

Moreover, in addition to this lack of inclusiveness, the handling of ILUC risk in Europe has also been marred by widespread complaints of intransparency, particularly where the evaluation and critique of relevant scientific knowledge and evidence is concerned. Such a dynamic was clearly evident, for instance, during an official stakeholder meeting held in Brussels by the European Commission to address ILUC in September 2010. This meeting 
was controversial not just because it was accessible only to a highly exclusive group of stakeholders, but also because it witnessed high-level policy officials actively preclude discussion of the very scientific studies into ILUC upon which the meeting was itself predicated. Shortly afterwards, several NGOs therefore accused the Commission in a public letter of '[failing] to meet...the most basic principle of public participation in policymaking', and of exhibiting a 'pattern of scientific obfuscation and intransparent working' (Rankin, 2010). Perhaps most worryingly, such obfuscation was not deemed particularly novel at the time; similar intransparency had been exhibited earlier in the debate by virtue of the Commission's refusal to grant access to scientific documents under a Freedom of Information request launched by various stakeholders in late 2009 (Milouchev, 2009). Unsurprisingly, such trends have lead to a widespread view of the Commission's practices in this case as at best intransparent, and at worst potentially corrupt (Harrison, 2010).

Beyond a simple lack of inclusivity and transparency however, these dynamics arguably also sit directly at odds with additional calls for the more adaptable ${ }^{13}$ and reflexive governance of risk in an age of increasing complexity and uncertainty (Fischer, 2009; Hoppe, 2010). Here, predominantly quantitative and technocratic risk assessment techniques predicated upon the Enlightenment notions of instrumental rationality and "speaking truth to power" (Collingridge and Reeve, 1986) - such as ILUC modelling and ILUC factors in this case - have been widely critiqued for yielding a distorted view of the risk regulation process as little more than 'context-free technical problem solving' (Forester, 1993) - and therefore for failing to recognise that 'social and cultural commitments are built into every phase of knowledge production'14 (Jasanoff and Wynne, 1998).

\footnotetext{
${ }^{13}$ Arguably calls for more adaptable policymaking are not new at all; such ideas were probably first conveyed by Charles Lindblom (1959) in his seminal article on the "science of muddling through".

${ }^{14}$ The often sophisticated ways in which risk assessors actively seek to obscure these commitments has been eloquently elucidated in the case of global climate modelling, for instance, by Shackley and Wynne (1996).
} 
In place of such techniques, scholars in this field have repeatedly called for novel, less restricted modes of reasoning to be employed when confronting wicked problems. Sanderson (2006: 126), for instance, advocates what he terms "practical rationality", which would encourage decision-makers to make 'wise judgements about the appropriateness of policy action in relation to a range of technical, political, moral and ethical concerns.' Similarly, Flyvbjerg (2004: 402) has called for the revival of phronesis (an Aristotelian concept with no contemporary analogue), whereby the value of 'practical knowledge and wisdom' (Owens et al., 2004: 1948) is recognised as equal to that of scientific knowledge and technical skill. Using slightly different terminology again, Fischer (2009) calls for "practical reason" to be given a more prominent role alongside instrumental rationality in risk regulation, thereby promoting a finer balance between technical and experiential knowledge in the decisionmaking process. Crucially, what each of these - and indeed a host of other - authors shares in common is a desire to reconstitute the relationships between science, values and politics underpinning contemporary risk governance, thereby placing technical and scientific pronouncements on an equal footing with a range of other "knowledge traditions" (Turnbull, 1997), whilst at the same time opening up the many normative dimensions of wicked problems to wider public scrutiny.

For Funtowicz and Ravetz (1993), these principles have collectively been evoked in calls for a shift towards "post-normal science", whereby an extended peer community of diversely predisposed actors is actively encouraged to reflect upon, and constructively critique, existing framings of, and knowledge and evidence pertaining to, wicked problems. Whatever the precise terminology used to describe these ideas, in light of the incertitudes identified as characterising wicked problems above, such shifts would - critically - facilitate an open and explicit questioning of what it is that actually constitutes "good" and "effective" risk governance in the first place, thereby "opening up" rather than "closing down" political 
discussions about a wide range of individual issues ${ }^{15}$. Unfortunately, to date, the characteristics exhibited by the European governance of ILUC - namely exclusivity, intransparency, inertia, and a near total lack of reflexivity - have failed categorically to live up to these ideals.

\section{Conclusions}

This paper has shown that indirect land-use change is an archetypal "wicked problem" (Rittel \& Webber, 1973) characterised by 'uncertainty over consequences, diverse and multiple engaged interests, conflicting knowledge claims, and high stakes' (Lorenzoni et al., 2007: 65). A complex range of incertitudes (including uncertainty, indeterminacy, ambiguity and ignorance) have been demonstrated as fundamentally constitutive of this problem, and are argued here to render the crucial epistemological tasks of identifying and interpreting relevant knowledge and evidence hugely difficult. Thus, even the question "What are the main reasons for considering ILUC problematic?" is a far from uncontested one, at least outside of certain factions in Brussels. Despite these incertitudes however, the risk governance apparatus deployed thus far to tackle the problem of ILUC in Europe has led to the reification of an extremely narrow, technocratic discourse emphasising only the GHG impacts of this process. Moreover, the wider effects of this discourse have been to "close down" wider political debates in Brussels, thereby excluding arguments predicated upon a host of equally legitimate, alternative framings of the issue. In this way, existing European risk governance procedures have categorically failed to live up to widely espoused ideals of inclusiveness, transparency, adaptability and reflexivity being voiced in academic debates about the political implications of wicked problems.

\footnotetext{
${ }^{15}$ In the context of climate change for instance, Hulme (2009) has eloquently argued the need for a full, inclusive debate regarding the aims and goals of modern society, albeit without using the term phronesis directly.
} 
The effective and legitimate governance of risks emanating from wicked problems requires far more than the simple, direct application of knowledge that has been unproblematically derived from objective scientific enquiry. Indeed, as this paper has shown in the case of ILUC, knowledge and evidence about wicked problems often cannot be derived in such an objective manner, and must instead be recognised as co-produced by the interactions of a range of knowledge traditions (Jasanoff, 2004; Turnbull, 1997), each characterised by its own practices and discourses. Yet, perhaps because calls for new modes and institutions of risk governance have often lacked any real precision in defining feasible alternatives to the present paradigm of "context free, technical problem solving" (Fischer, 1993), reductive, quantitative methodologies today remain virtually 'synonymous with the application of science in risk assessment', especially in élite policy circles (Stirling, 2003: $37)$.

When faced with wicked problems, more deliberative and inclusive decision-making procedures, capable of weaving together diverse types of knowledge (drawing from both scientific and non-scientific traditions), as well as normative judgements regarding the moral and ethical defensibility of different courses of action, are argued here to be highly desirable. The sheer scale of the institutional transformations that this shift would require in the contemporary European context is undoubtedly vast. Yet it is also true that to at least seek ways of actively welcoming (rather than eschewing) the contributions of an "extended peer community" (Funtowicz \& Ravetz, 1993) to what is otherwise a narrowly informed and highly technocratic risk governance process would be an immediately achievable goal for European risk regulators. Perhaps it is only once the validity of this goal has been recognised, and with a wider range of normative values and perspectives subsequently on the table, that more substantive shifts in the institutional fabric of European risk regulation will become a genuine possibility. 


\section{Acknowledgements}

This research was funded by the UK Economic and Social Research Council (Award No.

ES/GO13195/1). It benefits from the insights of a number of individuals who generously gave their time as anonymous interviewees. The author would like to thank Prof. Susan

Owens for her helpful feedback and advice on an earlier draft. Comments made by two anonymous referees also helped to improve the paper significantly. Any remaining errors are entirely the author's own.

\section{References}

Al-Riffai, P., Dimaranan, B. and Laborde, D. 2010. Global Trade and Environmental Impact Study of the EU Biofuels Mandate, Final Report, March 2010. International Food Policy Research Institute, Washington, D.C.

Ariza-Montobbio, P., Lele, S., Kallis, G. and Martinez-Alier, J. 2010. 'The political ecology of Jatropha plantations for biodiesel in Tamil-Nadu, India.' The Journal of Peasant Studies 37(4): 875-897

Bailey, R. 2008. Another Inconvenient Truth: How biofuel policies are deepening poverty and accelerating climate change. Oxfam Briefing Paper 114, Oxfam International, Oxford.

Beck, U. 1992. Risk Society: Towards a New Modernity. Sage Publications, London.

Berkhout, F., Hertin, J. and Jordan, A. 2002. "Socio-economic futures in climate change impact assessment: Using scenarios as learning machines." Global Environmental Change 12: 83-95.

Bowyer, C. 2010. Anticipated Indirect Land Use Change Associated with Expanded Use of Biofuels and Bioliquids in the EU - An Analysis of the National Renewable Energy Action Plans. Institute for European Environmental Policy, London.

Carmody, P. 2011. The New Scramble for Africa. Polity Press, Cambridge.

Chakrabortty, A. 2011. Bankers and politicians have turned food into a betting game. The Guardian, $7^{\text {th }}$ June 2011. Available at: http://www.guardian.co.uk/commentisfree/2011/jun/07/bankers-politicians-foodbetting-game [Accessed 13th June 2011].

Clift, R. and Mulugetta, Y. 2007. 'A Plea for Common Sense (and Biomass).' The Chemical Engineer, October 2007: 24-26.

Collingridge, D. and Reeve, C. 1986. Science Speaks to Power: The Role of Experts in Policy Making. Frances Pinter Publishers, London.

Collins, H. And Pinch, T. 1998. The Golem: What You Should Know About Science, $2^{\text {nd }}$ Edition. Cambridge University Press, Cambridge.

Cornelissen, S. \& Dehue, B. 2009. Summary of approaches to accounting for indirect impacts of biofuel production. Ecofys, Utrecht, NL. Available at: http://www.ecofys.nl/com/publications/documents/Summaryofapproachestoaccountin gforindirectimpactsofbiofuelproduction.pdf [Accessed October 22, 2010]. 
Danielsen, F., Beukema, H., Burgess, N.D., Parish, F., Brühl, C.A., Donald, P.F., Murdiyarso, D., Phalan, B., Reijnders, L., Struebig, M. and Fitzherbert, E.B. 2008. 'Biofuel plantations on forested lands: Double jeopardy for biodiversity and climate.' Conservation Biology 23(2): 348-358.

De Marchi, B., Ravetz, J.R. 1999. 'Risk management and governance: A post-normal science approach.' Futures 31: 743-757.

DG Energy. 2010. The Impact of Land Use Change on Greenhouse Gas Emissions from Biofuels and Bioliquids. European Commission, Brussels. Available at: http://ec.europa.eu/energy/renewables/consultations/doc/public_consultation_iluc/stud y_3_land_use_change_literature_review_final_30_7_10.pdf [Accessed October 21, 2010].

Dunlop, C.A. 2010. 'The temporal dimension of knowledge and the limits of policy appraisal: biofuels policy in the UK.' Policy Sciences 43(4): 343-363.

Edwards, R., Mulligan, D. and Marelli, L. 2010. Indirect Land Use Change from increased biofuels demand: Comparison of models and results for marginal biofuels production from different feedstocks. European Commission Joint Research Centre, Ispra, Italy.

EC. 2003. 'Directive 2003/30/EC of the European Parliament and of the Council of $8^{\text {th }}$ May 2003 on the promotion of the use of biofuels or other renewable fuels for transport.' Official Journal of the European Union L123, 42-46, $17^{\text {th }}$ May. European Commission, Brussels. Available at: http://eurlex.europa.eu/LexUriServ/LexUriServ.do?uri=OJ:L:2003:123:0042:0046:EN:PDF [Accessed $9^{\text {th }}$ June 2011].

EC. 2009a. 'Directive 2009/28/EC of the European Parliament and of the Council of 23rd April 2009 on the promotion and use of energy from renewable sources and amending and subsequently repealing Directives 2001/77/EC and 2003/30/EC.' Official Journal of the European Union L140, 16-62, $15^{\text {th }}$ June. European Commission, Brussels. Available at: http://www.energy.eu/directives/pro-re.pdf [Accessed 9th June 2011].

EC. 2009b. Indirect Land Use Change - Possible elements of a policy approach. European Commission, Brussels. Available at: http://ec.europa.eu/energy/renewables/consultations/doc/iluc_preparatory_consultatio n_doc.pdf [Accessed 9th June 2011].

EC. 2010a. COM (2010) 811 final: Report from the Commission on indirect land-use change related to biofuels and bioliquids. European Commission, Brussels. Available at: http://ec.europa.eu/energy/renewables/biofuels/doc/land-usechange/com_2010_811_report_en.pdf [Accessed 9th June 2011].

EC. 2010b. Indirect Land Use Change Impacts of Biofuels - Consultation. European Commission, Brussels. Available at: http://ec.europa.eu/energy/renewables/consultations/doc/public_consultation_iluc/lan d_use change_consultation_final.pdf [Accessed 9th June 2011].

Fargione, J., J. Hill, D. Tilman, S. Polasky, and P. Hawthorne. 2008. 'Land Clearing and the Biofuel Carbon Debt.' Science 319(5867): 1235-1238.

Fischer, F. 2009. Democracy and Expertise. Oxford University Press, Oxford.

Fischer, F. and Forester, J. (eds.) 1993. The Argumentative Turn in Policy Analysis and Planning. UCL Press, London.

Flyvbjerg, B. 2004. 'A Perestroikan Straw Man Answers Back: David Laitin and Phronetic Political Science.' Politics \& Society 32(3): 389 -416.

Forester, J. 1993. Critical Theory, Public Policy and Planning Practice: Toward Critical Pragmatism. State University of New York Press, NY. 
Friends of the Earth Europe. 2007. Agrofuels: Fuelling of fooling Europe? Press Release, available at: http://www.foe.co.uk/resource/briefings/agrofuels_fuelling_or_fool.pdf [Accessed $9^{\text {th }}$ June 2011.

Funtowicz, S.O. \& Ravetz, J.R. 1993. 'Science for the post-normal age'. Futures 25(7): 739755.

Giddens, A. 1990. The Consequences of Modernity. Polity Press, Cambridge.

Hajer, M.A. 1995. The politics of environmental discourse: ecological modernization and the policy process. Oxford University Press, Oxford.

Harrison, P. 2010. 'Special Report - Europe finds biofuels and politics don't mix', $5^{\text {th }}$ July 2010. Reuters.com. Available at: http://uk.reuters.com/article/2010/07/05/uk-biofuelseurope-idUKTRE6641G020100705 [Accessed 13th June 2010].

Hoppe, R. 2010. 'Lost in translation? Boundary work in making climate change governable', in P.P.J. Driessen, P. Leroy and W. van Vierssen (eds.) From Climate Change to Social Change: Perspectives on Science-Policy Interactions. International Books, Utrecht, NL.

Hulme, M. 2009. Why We Disagree About Climate Change. Cambridge University Press, Cambridge.

Jasanoff, S. 2004. States of knowledge: the co-production of science and social order. Routledge, London.

Jasanoff, S. and Wynne, B. 1998. 'Science and Decisionmaking', in S. Rayner and E. Malone (eds), Human Choice and Climate Change: The Societal Framework. Batelle Press, Ohio: $1-87$.

Kingdon, J. 2003. Agendas, Alternatives and Public Policies. Longman, New York.

Knight, F.H. 1921. Risk, Uncertainty and Profit. Houghton Mifflin, Boston, MA.

Koh, L. P. and Ghazoul, J. 2008. 'Biofuels, biodiversity and people: Understanding the conflicts and finding opportunities.' Biological Conservation 141: 2450-2460.

Kutas, G., Lindberg, C. and Steenblik, R. 2007. Biofuels: At What Cost? Government Support for Ethanol and Biodiesel in the European Union. Global Studies Initiative, International Institute for Sustainable Development, Geneva, SUI.

Laurance, W.F. 2007. 'Switch to Corn Promotes Amazon Deforestation.' Science 318: 1721.

Lorenzoni, I., Jones, M. and Turnpenny, J.R. 2007. 'Climate change, human genetics and post-normality in the UK.' Futures 39: 65-82.

Matondi, P.B., Havnevik, K. and Beyene, A. (eds.) 2011. Biofuels, Land-Grabbing and Food Security in Africa. Zed Books, London.

Milouchev, M. 2009. 'Letter to European Federation for Transport and Environment from the Directorate General for Agriculture', 27 November 2009. Available at: http://www.clientearth.org/reports/biofuels-schedule-of-annexes.pdf [Accessed 13th June 2011].

Mitchell, D. 2008. A Note on Rising Food Prices. Policy Research Working Paper 4682, Development Prospects Group, World Bank, Washington, D.C.

Ney, S. 2009. Resolving Messy Policy Problems: Handling Conflict in Environmental, Transport, Health and Ageing Policy. Earthscan, London.

Owens, S., Rayner, T. \& Bina, O. 2004. 'New agendas for appraisal: reflections on theory, practice, and research.' Environment and Planning A 36(11): 1943 - 1959.

Palmer, J. 2010. 'Stopping the unstoppable? A discursive-institutionalist analysis of renewable transport fuel policy.' Environment and Planning C: Government and Policy 28(6): 992-1010.

Pielke, Jr., R.A. 2007. The Honest Broker: Making Sense of Science in Policy and Politics. Cambridge University Press, Cambridge. 
Rankin, J. 2010. 'Biofuel policy "lacks transparency"', 30 September 2010,

EuropeanVoice.com. Available at:

http://www.europeanvoice.com/article/imported/biofuel-policy-lacks-transparency169027.aspx [Accessed 13th June 2011].

Ravindranath, N. H., R. Manuvie, J. Fargione, J. G. Canadell, G. Berndes, J. Woods, H. Watson, and J. Sathaye. 2009. 'Greenhouse Gas Implications of Land Use and Land Conversion to Biofuel Crops' in Biofuels: Environmental Consequences and Interactions with Changing Land Use, eds. R. W. Howarth and S. Bringezu, pp. 111125 (Proceedings of the Scientific Committee on Problems of the Environment (SCOPE) International Biofuels Project Rapid Assessment, 22-25 September 2008, Gummersbach, Germany).

RFA. 2008. The Gallagher Review of the Indirect Effects of Biofuel Production. Renewable Fuels Agency, East Sussex.

Rittel, H.W.J. and Webber, M.W. 1973. 'Dilemmas in a General Theory of Planning.' Policy Sciences 4: 155-69.

Ros, J.P.M., Overmars, K.P., Stehfest, E., Prins, A.G., Notenboom, J. and van Oorschot, M. 2010. Identifying the indirect effects of bio-energy production. Netherlands Environmental Assessment Agency, Bilthoven, NL.

Royal Society. 2008. Sustainable Biofuels: Prospects and Challenges. Policy Document 01/08. Available at: http://royalsociety.org/Sustainable-biofuels-prospects-andchallenges/ [Accessed $9^{\text {th }}$ June 2011].

RSPB. 2008. A Cool Approach to Biofuels. Royal Society for the Protection of Birds. Available at: http://www.rspb.org.uk/Images/Biofuels tcm9-187450.pdf [Accessed $9^{\text {th }}$ June 2011.

Sanderson, I. 2006. 'Complexity, “practical rationality” and evidence-based policymaking.' Policy \& Politics 34(1): 115-32.

Sarewitz, D. 2000. 'Science and Environmental Policy: An Excess of Objectivity', in R. Frodeman (ed.), Earth Matters: The Earth Sciences, Philosophy and the Claims of Community. Prentice Hall, London: 79-98.

Schön, D.A. \& Rein, M. 1994. Frame Reflection: Toward the Resolution of Intractable Policy Controversies. Basic Books, New York.

Searchinger, T., R. Heimlich, R. A. Houghton, F. Dong, A. Elobeid, J. Fabiosa, S. Tokgoz, D. Hayes, and T-H. Yu. 2008. 'Use of U.S. Croplands for Biofuels Increases Greenhouse Gases Through Emissions from Land-Use Change.' Science 319(5867): 1238-1240.

Searchinger, T., S. P. Hamburg, J. Melillo, W. Chameides, P. Havlik, D. M. Kammen, G. E. Likens, R. N. Lubowski, M. Obersteiner, M. Oppenheimer, G. P. Robertson, W. H. Schlesinger, and G. D. Tilman. 2009. 'Fixing a Critical Climate Accounting Error.' Science 326: 527-528.

Searchinger, T. 2010. 'Biofuels and the need for additional carbon.' Environmental Research Letters 5024007.

Shackley, S. and Wynne, B. 1996. 'Representing Uncertainty in Global Climate Change Science and Policy: Boundary-Ordering Devices and Authority.' Science, Technology and Human Values 21(3): 275-302.

Spiegelhalter, D. And Riesch, H. 2011. 'Don't know, can't know: Embracing deeper uncertainties when analysing risks.' Philosophical Transactions of the Royal Society A 369(1956): 4730-4750.

Stirling, A. 2003. 'Risk, uncertainty and precaution: Some instrumental implications from the social sciences', in F. Berkhout, M. Leach and I. Scoones (eds), Negotiating Environmental Change: New Perspectives from Social Science. Edward Elgar, London: 33-77. 
Stirling, A. 2008. “"Opening Up” and "Closing Down”. Science, Technology \& Human Values 33(2): 262 -294.

Stone, D. 1988. Policy Paradox and Political Reason. Scott, Foresman and Co., Glenview, IL.

The Times. 2008. 'Rush for biofuels threatens starvation on a global scale', $7^{\text {th }}$ March 2008. URL: http://www.timesonline.co.uk/tol/news/environment/article3500954.ece [Accessed $9^{\text {th }}$ June 2011.

Turnbull, D. 1997. 'Reframing science and other local knowledge traditions.' Futures 29(6): 551-562.

Vermeulen, S. And Cotula, L. 2010. 'Over the heads of local people: Consultation, consent, and recompense in large scale land deals for biofuel projects in Africa.' The Journal of Peasant Studies 37(4): 899-916.

Weinberg, A.M. 1972. 'Science and Trans-Science.' Minerva 10: 209-22.

Weis, T. 2010. 'The Accelerating Biophysical Contradictions of Industrial Capitalist Agriculture.' Journal of Agrarian Change 10(3): 315-341.

Woods, J. 2009. Bioenergy and indirect land-use change. Presentation delivered at UNEP, IPIECA, EPFL and RSB indirect land-use change conference, Lausanne, Switzerland, 9th November 2009. Available at: http://rsb.epfl.ch/files/content/sites/rsb2/files/Biofuels/Regional\%20Outreaches\%20\& \%20Meetings/2009/Nov\%202009\%20iLUC\%20Conference/Workman_Woods_ILU C_IPIECA_09nov09a\%20-\%20Final.pdf [Accessed 9th June 2011].

Wynne, B., Callon, M., Goncalves, M.E., Jasanoff, S., Jepsen, M., Joly, P-B., Konopasek, Z., May, S., Neubauer, C., Rip, A., Siune, K., Stirling, A. and Tallacchini, M. 2007. Taking European Knowledge Society Seriously. Report of the Expert Group on Science and Governance to the Science, Economy and Society Directorate, Directorate-General for Research, European Commission.

Yanow, D. 1996. How does a policy mean? Interpreting policy and organizational actions. Georgetown University Press, Washington, DC.

Figure Legends and Table Titles:

Figure 1: Schematic diagram illustrating the distinction between direct and indirect land-use change resulting from biofuel production (Source: Woods, 2009).

Figure 2: Schematic illustration of the three main stages of a typical indirect land-use change model, here oriented towards the estimation of GHG impacts (adapted from Cornellisen and Dehue, 2009: 11).

Figure 3: Graph plotting estimated GHG emissions resulting from land-use changes occasioned by a range of biofuels (as defined according to feedstock and geographical location of cultivation) (adapted from Edwards et al., 2010: 95).

Table 1: Outline of the diverse range of risks that can legitimately be associated with indirect land-use change.

Table 2: A proposed typology of incertitudes which may typically characterise wicked problems. 